\title{
Insulin Release from the Beta Cells in Acatalasemic Mice Is Highly Susceptible to Alloxan-Induced Oxidative Stress
}

\author{
Kazunori Takemoto', Wakana Doi'2, Ken Kataoka², Kohji Ishihara², Da-Hong Wang? \\ Hitoshi Sugiyama", Noriyoshi Masuoka2 ${ }^{*}$ \\ ${ }^{1}$ Medical Science Education Center, Okayama University of Science, Okayama, Japan \\ ${ }^{2}$ Department of Life Science, Faculty of Science, Okayama University of Science, Okayama, Japan \\ ${ }^{3}$ Department of Biochemistry, Faculty of Science, Okayama University of Science, Okayama, Japan \\ ${ }^{4}$ Department of Medicine and Clinical Science, Graduate School of Medicine, Dentistry, and Pharmaceutical \\ Sciences, Okayama University, Okayama, Japan \\ Email: ${ }^{*}$ masuokan@dls.ous.ac.jp
}

Received 26 March 2015; accepted 2 May 2015; published 5 May 2015

Copyright (C) 2015 by authors and Scientific Research Publishing Inc.

This work is licensed under the Creative Commons Attribution International License (CC BY). http://creativecommons.org/licenses/by/4.0/

(c) (i) Open Access

\section{Abstract}

Background: Catalase deficiency (acatalasemia) is sensitive to alloxan, and the administration to acatalasemic mice develops hyperglycemia under mild conditions. However, the mechanism is still poorly understood. Methods: Alloxan was used to induce the oxidative stress and intraperitoneally administered to acatalasemic and normal mice. The blood samples of these mice after 1, 3, 5 and 7 days were examined. The pancreatic islets 7 days after alloxan administration were isolated, and the insulin released under $3 \mathrm{mM}$ and $20 \mathrm{mM}$ glucose was examined. Results: After alloxan administration, increase of oxidative markers in blood and pancreatic apoptosis in acatalasemic mice were observed immediately. Insulin in blood was lowered after 3 days, and the insulin in acatalasemic mice was lower than that in normal mice. Hyperglycemia in the acatalasemic mice was observed after 3 days. The pancreatic islets after 7 days were isolated. A reduction of the insulin released from the islets under glucose stimulation was observed. The stimulation indexes of the normal and acatalasemic mice were $1.4 \pm 0.6$ and $0.7 \pm 0.3$, respectively. Conclusions: Alloxan induced a deterioration of glucose-dependent insulin secretion ability from the islets, and the deterioration mostly contributed to hyperglycemia, rather than apoptosis.

\section{Keywords}

Alloxan, Hyperglycemia, Acatalasemia, Insulin Release, Diabetes, Beta Cells

\footnotetext{
${ }^{*}$ Corresponding author.
}

How to cite this paper: Takemoto, K., Doi, W., Kataoka, K., Ishihara, K., Wang, D.-H., Sugiyama, H. and Masuoka, N. (2015) Insulin Release from the Beta Cells in Acatalasemic Mice Is Highly Susceptible to Alloxan-Induced Oxidative Stress. Journal of Diabetes Mellitus, 5, 81-89. http://dx.doi.org/10.4236/jdm.2015.52010 


\section{Introduction}

Catalase (EC1.11.1.6) plays a predominant role in the removal of hydrogen peroxide that is necessary to afford protection against the oxidative damage caused by high concentrations of hydrogen peroxide [1]. In 1948, Takahara and Miyamoto discovered deficiencies in erythrocyte catalase among some Japanese patients who had oral gangrene [2]. They named this congenital absence of erythrocyte catalase as acatalasemia, later called "Takahara’s disease” [3]. Recently Goth et al. reported a high incidence of diabetes mellitus in Hungarian acatalasemia patients [4]. To make clear the reason why the high incidence of diabetes in acatalasemia patients was observed, we have examined acatalasemic mice established by Feinstein et al. [5] and normal mice by intrapenitoneal injection of diabetogenic alloxan [6]-[9]. Since it is known that alloxan generates reactive oxygen species by acting as a reducing agent in the body and selectively injures $\beta$-cells in the pancreas so as to cause insulin dependent diabetes mellitus [10] [11]. We indicated that alloxan generated hydrogen peroxide in vitro. Acatalasemic mice became hyperglycemic with a smaller amount of alloxan and the incidence of hyperglycemia was higher than normal mice. Insulin level in acatalasemic blood became lower than normal, and the insulin resistance was not observed. Increase of apoptosis in Langerhans islets was observed in acatalasemic mice but in normal mice. Finally, we deduced that acatalasemic mice promoted diabetes mellitus faster and more frequently than normal mice.

However, as the most part of these studies were carried out after one week from alloxan administrations, it is still unclear the exact point at which mice begin to suffer hyperglycemia after alloxan administration. At first, we examined glucose, insulin and oxidative stress markers in the blood and then apoptosis in the pancreas 1, 3, 5 and 7 days post alloxan administration. We also examined insulin release from the Langerhans islets isolated from alloxan-treated mice under glucose stimulation to investigate what kind of oxidative damage occurs in the pancreas, since it is widely accepted that diabetes is associated with reactive oxygen species, which contribute to pancreatic cell damage and dysfunction in both type 1 and type 2 diabetes [12].

\section{Materials and Methods}

\subsection{Materials}

Male mice of the C3H/AnL CS $\mathrm{CS}^{\mathrm{a}}$ (normal) and C3H/AnL CS ${ }^{\mathrm{b}} \mathrm{CS}^{\mathrm{b}}$ (acatalasemia) strains established by Feinstein et al. were maintained on a laboratory diet (CE-2 diet, Clea Japan, Tokyo, Japan) and water ad libitium. The experimental procedure was approved by the Ethics Review Committees for Animal Experimentation of Okayama University of Science. Catalase activity in the media was determined by our previously reported method [13].

\subsection{Animal Experiments}

Acatalasemic mice (23 \pm 2 g) and normal mice (27 \pm 2 g) (12 weeks old) were divided into two groups. One group was intraperitoneally administered alloxan (200 mg/kg of body weight) [6] [14], the other served as a control was treated with phosphate buffered saline (PBS). Each mouse group was starved for 20 hrs, and blood glucose of each mouse was determined. For examination of the blood and pancreas, the starved mice were sacrificed 1, 3, 5 and 7 days after the administration. The blood and pancreas were collected. Heparin was used as an anticoagulant, and the plasma was stored at $-80^{\circ} \mathrm{C}$ until it was used for analysis.

\subsection{Determination of Glucose in the Blood}

Glucose content in the blood obtained from the tail of $20 \mathrm{hr}$-starved mice was determined. As the volume for the determination of blood glucose was small (approximately $2 \mu \mathrm{L}$ ), the glucose content in the blood was measured with a “Glucose-Test-Ace R” apparatus (Sanwa Kagaku Kenkyusho Co., Nagoya, Japan) applying a glucose oxidase method.

\subsection{Determination of Insulin and C-Peptide Levels in the Blood}

Insulin and C-peptide levels in the plasma were determined using Mouse Insulin and C-peptide ELISA kits (Shibayagi, Gunma, Japan). Each determination was carried out according to the manufacturer's instructions. A 
biotin-conjugated anti-insulin antibody $(100 \mu \mathrm{L})$ was added to each well of an antibody-coated 96 well plate. To the well, $10 \mu \mathrm{L}$ of sample or standard solutions were added and reacted for $2 \mathrm{hrs}$. Then, $100 \mu \mathrm{L}$ of peroxidaseconjugated avidin solution were added and reacted for $30 \mathrm{~min}$. Chromogenic substrate solution $(100 \mu \mathrm{L})$ was added and reacted for $30 \mathrm{~min}$. The reaction was terminated and the absorbance at $450 \mathrm{~nm}$ (sub-wave length, 620 $\mathrm{nm})$ was recorded.

\subsection{Measurement of Oxidative Stress Markers in the Blood}

Lipid peroxide in the plasma was determined using a color reaction of malonyl dialdehyde and 4-hydroxyalkenals (OXIS Health Products Inc., CA, USA). 8-Hydroxydeoxy guanidine (8-OHdG) in the plasma was determined using an Amicon Ultra 10K device (Merck, Germany) and a highly sensitive ELISA kit for 8-OHdG (JaICA, Tokyo, Japan).

\subsection{Microscopic Studies in the Pancreas}

1, 3, 5 and 7 Days after alloxan administration, mice were sacrificed and each animal's pancreatic tissue was isolated, fixed in Bouin's fluid and embedded in paraffin. Serial sections $(4 \mu \mathrm{m})$ were cut from each paraffinembedded tissue block. After staining, the stained cells in each tissue section were recorded with an FX380 CCD Cameraunder microscopy (Olympus, Tokyo, Japan), and these cells were counted manually from the images. For the measurements in the photographs, the Image J program (NIH) was used.

\subsubsection{Apoptosis Analysis}

Terminal deoxynucleotidyl transferase-mediated dUTP nick end labeling (TUNEL) staining was carried out using the In Situ Cell Death Detection Kit (Roche Diagnostics Japan) [15]. The apoptosis incidence was calculated from the TUNEL-positive cells per the total cells in the pancreatic islets.

\subsubsection{Additional Staining Procedures}

Sections were also stained with hematoxylin-eosin, Elastica van Gieson, 8-OHdG monoclonal antibody (MOG020, Japan Institute for the Control of Aging) [16], protein-carbonyl immunohistochemical (Cosmo Bio. Co. Ltd, Tokyo, Japan) [17] and mouse anti-insulin antibody (H-86, sc-9168, Santa Cruz Biotechnology and Vectastain Elite ABC rabbit IgG, Vector Lab.) stains for visualization by light microscopy.

\subsection{Isolation of Pancreatic Islets from the Mouse Pancreas}

1, 3, 5 and 7 Days after alloxan administration, mice were sacrificed. Islets were isolated from the pancreas [18]. Five mL of collagenase solution (type IV, $160 \mathrm{U} / \mathrm{ml}$, Worthington Biochem. Corp., NJ, USA) in Hank's balanced salt solution ( $\mathrm{pH}$ 7.4, Sigma-Aldrich Co. LLC) was injected into the common bile duct of each mouse. The pancreas was taken and incubated with $1 \mathrm{~mL}$ of collagenase solution at $37^{\circ} \mathrm{C}$ for $30 \mathrm{~min}$. Digested pancreatic tissue was washed three-times with $5 \mathrm{~mL}$ of Hank's balanced salt solution. The suspension was centrifuged at $700 \mathrm{X} \mathrm{g}$ for $10 \mathrm{~min}$. using a discontinuous gradient of Ficoll (Nacalai Tesque, Kyoto) at concentrations of 25\%, 23\%, $20 \%$ and $11 \%$ (2.0, 2.0, 2.0 and $1.0 \mathrm{~mL}$, respectively) in Hank's solution. Islets were taken up with a micropipette from the interface between the $20 \%$ and $11 \%$ layers, and centrifuged. To the precipitate, $5 \mathrm{~mL}$ of RPIM 1640 medium (pH 7.4, Invitrogen Corp. CA, USA) were added twice and washed out. Purified islets were cultured in $5 \mathrm{~mL}$ of RPMI 1640 medium at $37^{\circ} \mathrm{C}$ under air containing $5 \% \mathrm{CO}_{2}$ for $60 \mathrm{~min}$ and used for the experiments.

\subsection{Assay of Insulin or C-Peptide Release under Glucose Stimulation}

According to the manufacturer's instructions (Pancreatic islet culture kit, Cosmo Bio. Co. Ltd), $0.5 \mathrm{~mL}$ of RPIM 1640 medium containing $3 \mathrm{mM}$ glucose ( $\mathrm{pH}$ 7.4) was added to ten purified islets, and the suspension was incubated at $37^{\circ} \mathrm{C}$ for $60 \mathrm{~min}$ under $5 \% \mathrm{CO}_{2}$. After centrifugation, the supernatant was removed. To the residue (the precipitated islets), $0.5 \mathrm{~mL}$ of RPIM 1640 medium containing $3 \mathrm{mM}$ glucose was added, and the suspension was incubated at $37^{\circ} \mathrm{C}$ for 60 min under $5 \% \mathrm{CO}_{2}$. The suspension was centrifuged again, and the supernatant was collected for analysis as the sample was stimulated with $3 \mathrm{mM}$ glucose. To the residue, $0.5 \mathrm{~mL}$ of medium 
containing $20 \mathrm{mM}$ glucose was added and the mixture was incubated at $37^{\circ} \mathrm{C}$ for a further 60 min under $5 \% \mathrm{CO}_{2}$. The suspension was centrifuged, and the supernatants were collected for analysis as the sample stimulated with $20 \mathrm{mM}$ glucose. These supernatants were stored at $-80^{\circ} \mathrm{C}$ until analysis. The insulin and C-peptide levels in the supernatant were determined using Mouse Insulin and C-peptide ELISA kits (Shibayagi), and the total DNA content in each sample was measured with a CyQUANT assay (Invitrogen). In order to estimate the function of the islets for glucose stimulation, the stimulation indexes of insulin and C-peptide from the islets were calculated [19]. The stimulation index was dividing the insulin (or C-peptide) level stimulated with $20 \mathrm{mM}$ glucose by the level stimulated with $3 \mathrm{mM}$ glucose.

\subsection{Statistics}

Student's t-test was used to evaluate the statistical significance of difference. The difference was considered significant when $\mathrm{p}<0.05$.

\section{Results}

Catalase activity in acatalasemic mouse blood at $25^{\circ} \mathrm{C}$ was $0.15 \pm 0.09 \mu \mathrm{mol} / \mathrm{s} / \mathrm{g}$ of $\mathrm{Hb}$ and the activity in normal mouse blood was $6.89 \pm 0.57 \mu \mathrm{mol} / \mathrm{s} / \mathrm{g}$ of $\mathrm{Hb}$.

\subsection{Blood Glucose in Normal and Acatalasemic Mice}

Blood glucose level in both groups of mice became lower one day after alloxan administration (Figure 1). Both levels were significantly low ( $<0.05)$ compared to those of the control. Then, the level in the normal mice was slowly increased near the control level, and that in the acatalasemic mice was significantly increased after 3 days resulting in hyperglycemia $(\mathrm{p}=0.053, \mathrm{p}<0.05)$. The incidence of hyperglycemia was indicated in Table 1 .

\subsection{Insulin in Normal and Acatalasemic Mouse Blood}

The insulin concentration in normal and acatalasemic mouse blood transiently increased one day after alloxan administration and then decreased (Figure 2). After 3 days from alloxan administration the insulin level of both mice became low, and the insulin level of the acatalasemic mice was always lower than that of the normal mice.

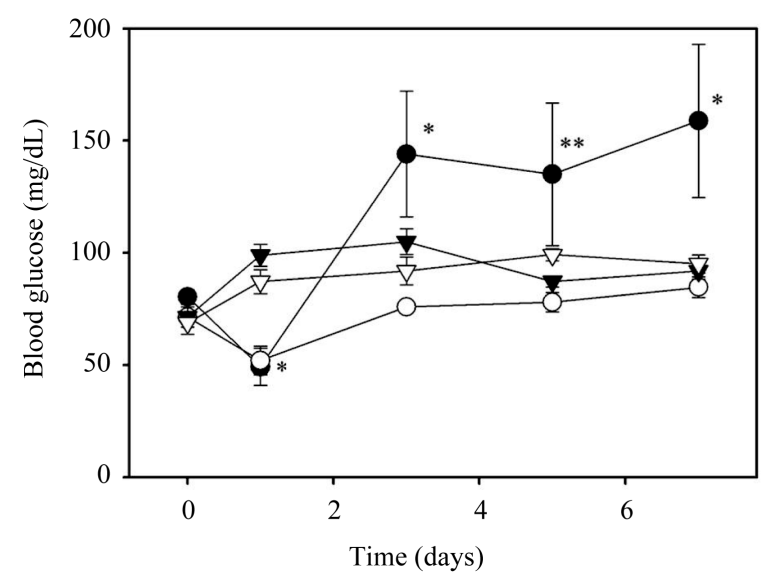

Figure 1. Blood glucose of fasting mice after alloxan administration. Alloxan was administered to each mouse on day 0 , and mouse blood glucose on 0,1 st, 3rd, 5th and 7th days was determined. Closed circles indicate acatalasemic mice $(\mathrm{n}=$ $15)$, and open circles normal mice $(n=15)$ treated with alloxan. Closed triangles indicate acatalasemic mice treated with PBS ( $n=6)$ as a control, and open triangles indicate the control of normal mice $(n=4)$. The bars of each symbol indicate the SE. * and $* *$ indicate $\mathrm{p}<0.05$ and $\mathrm{p}=0.053$, respectively, compared to the control mice. 
Table 1. Incidence of hyperglycemia in the mouse blood after alloxan administration.

\begin{tabular}{ccccccc}
\hline \multirow{2}{*}{ Mice } & $\begin{array}{c}\text { Alloxan } \\
(\mathrm{mg} / \mathrm{kg})\end{array}$ & 0 days & 1 days & 3 days & 5 days & 7 days \\
\cline { 3 - 7 } & 0 & 0 & 0 & 0 & 0 & 0 \\
Normal $^{*}(3)$ & 200 & 0 & 0 & 0 & 0 & 10 \\
Normal (10) $_{\text {Acatalasemia* }}^{*}(3)$ & 0 & 0 & 0 & 0 & 0 & 0 \\
Acatalasemia (15) & 200 & 0 & 0 & 27 & 33 & 53 \\
\hline
\end{tabular}

*Mice were treated with PBS as a control. Number in parenthesis indicates the number of mice. Hyperglycemia for mice is $>126$ mg/dL of blood glucose, which is determined from average fasting mouse blood glucose $(77 \pm 23 \mathrm{mg} / \mathrm{dL})$.

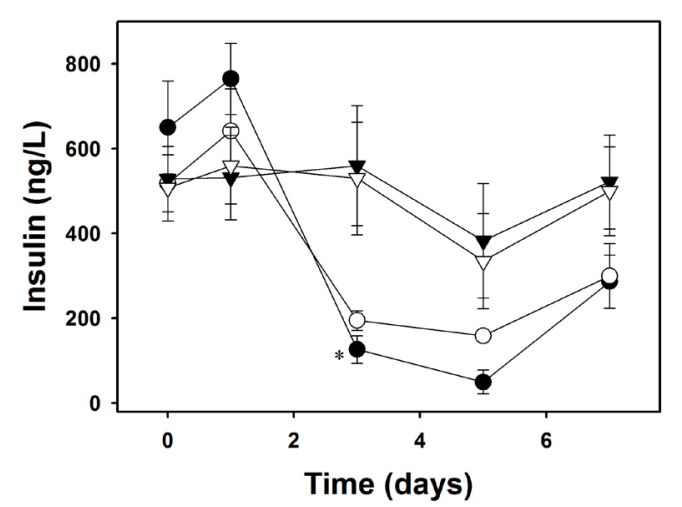

\begin{abstract}
Figure 2. Insulin in mouse blood after alloxan administration. Alloxan was administered to normal and acatalacemic mice on day 0 , and insulin in the blood was determined. Each open circle represents the normal mice $(n=6)$, and the closed circle is acatalasemic mice $(n=6)$ treated with alloxan. The open triangles indicate normal mice $(n=6)$ treated with PBS $(n=6)$ as a control, and the closed triangles are the control of acatalasemic mice $(n=4)$. The bars of each symbol indicate the SE. *indicates $\mathrm{p}<0.05$ compared to the control mice.
\end{abstract}

\title{
3.3. Oxidative Stress Markers in Normal and Acatalasemic Mouse Blood
}

Oxidative stress markers in normal and acatalasemic mouse bloods increased after alloxan administration (Figure 3). These oxidative stress markers were considerably higher than the control 7 days after alloxan administration as we previously reported [8]. As these marker levels in acatalasemic blood are similar to normal ones, it suggests that these markers are not directly generated by reactions of hydrogen peroxide.

\subsection{Microscopic Studies of Mouse Pancreatic Tissues}

\subsubsection{Apoptosis in $\beta$ Cells after Alloxan Administration}

Apoptosis was calculated using TUNEL-positive cells per the total cells in the islets of Langerhans. After alloxan administration, pancreatic apoptosis in acatalasemic mice immediately increased (Table 2) though the increase was low (less than 6.2\%). The increase was kept for more than 7 days. Increase of pancreatic apoptosis in normal mice was not observed.

\subsubsection{Protein-Carbonyl and 8-OHdG Immunohistochemical Staining in the Mouse Pancreas}

As the result of alloxan administration, mild increase of oxidized protein was observed on the inside of islets in the alloxan administrated group (Figure 4). It indicated that the increase in acatalasemic mice was larger than normal one.

In the case of 8-OHdG staining, the stained cells in normal and acatalasemic mice were hardly observed 1, 3, 5 and 7 days after alloxan administration (data not shown). It might be due to the low incidence of apoptosis in mouse pancreas. 


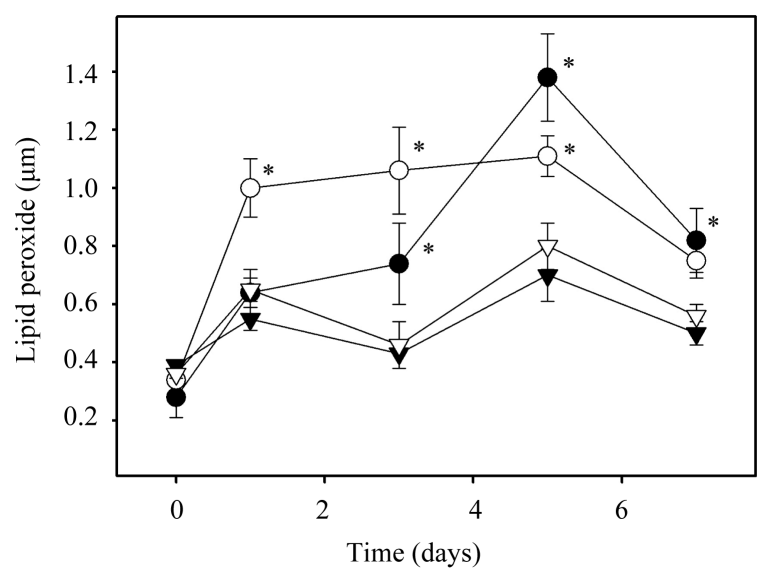

(a)

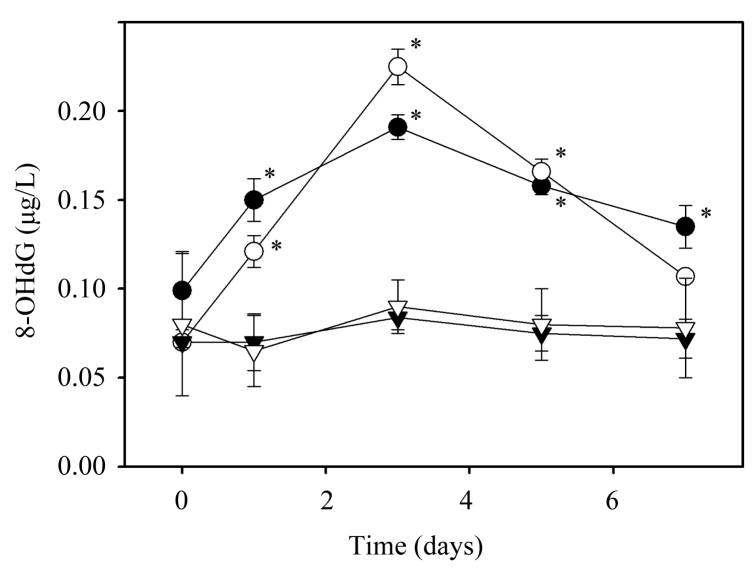

(b)

Figure 3. Lipid peroxide and 8-OHdG in the fasting mouse blood after alloxan administration. Alloxan was administered on day 0 to normal and acatalacemic mice. (a) indicates the lipid peroxide in the mouse blood and (b) 8-OHdG in the blood. Each open circle represents normal mice $(n=6)$ treated with alloxan, and the closed circle is the acatalasemic mice $(n=6)$. The open triangles indicate normal mice $(n=6)$ treated with PBS as a control, and the closed triangles are the control of acatalasemic mice $(n=4)$. The bars of each symbol indicate the SE. *indicates $p<0.05$ compared to the control mice.

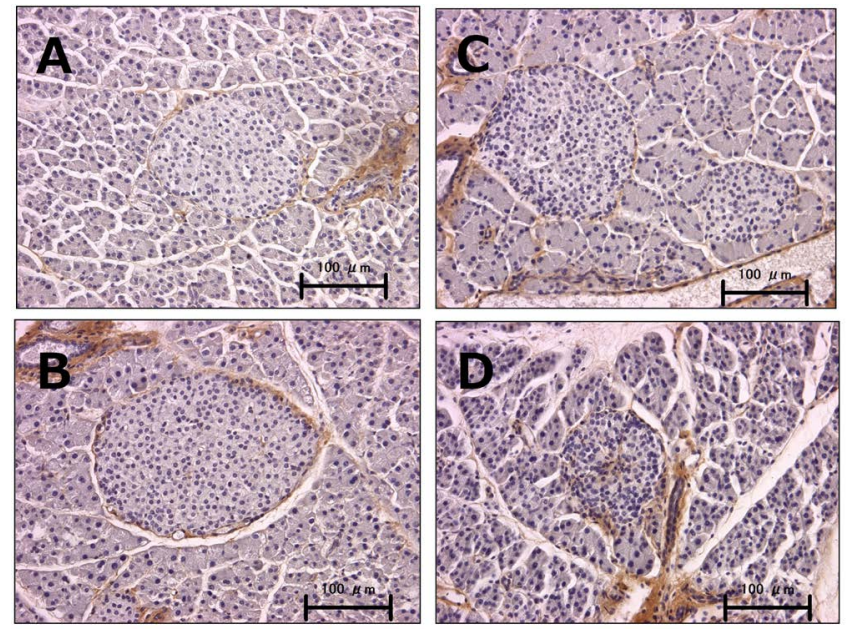

Figure 4. Protein-carbonyl immunohistochemical stains in the mouse pancreas 7 days after alloxan administration. (A) Normal mice treated with PBS as a control, (B) normal mice treated with alloxan, (C) control of acatalasemic mice and (D) acatalasemic mice treated with alloxan.

Table 2. Apoptosis in the pancreatic tissues after alloxan administration.

\begin{tabular}{|c|c|c|c|c|c|}
\hline \multirow{2}{*}{ Mice $(\geq 3)$} & \multirow{2}{*}{$\begin{array}{l}\text { Alloxan } \\
(\mathrm{mg} / \mathrm{kg})\end{array}$} & \multicolumn{4}{|c|}{ Incidence of apoptosis (\%) } \\
\hline & & 0 days & 1 days & 3 days & 7 days \\
\hline Normal ${ }^{*}$ & 0 & $0.9 \pm 0.1$ & $1.0 \pm 0.5$ & $0.9 \pm 0.1$ & $0.9 \pm 0.3$ \\
\hline Normal & 200 & $1.0 \pm 0.2$ & $0.8 \pm 0.4$ & $0.8 \pm 0.4$ & $1.0 \pm 0.4$ \\
\hline Acatalasemia $^{*}$ & 0 & $1.5 \pm 0.7$ & $2.3 \pm 0.2$ & $0.9 \pm 0.2$ & $1.3 \pm 0.4$ \\
\hline Acatalasemia & 200 & $1.4 \pm 0.6$ & $7.4 \pm 0.8^{* *}$ & $7.1 \pm 0.4^{* *}$ & $4.5 \pm 0.9^{* *}$ \\
\hline
\end{tabular}

${ }^{*}$ Mice were treated with PBS as a control. ${ }^{* *} \mathrm{p}<0.05$ compared to the control mice. 


\subsubsection{Anti-Insulin Antibody Stain in Pancreas}

After alloxan administration, numbers of $\beta$ cells in normal and acatalasemic mice were decreased and the numbers in the acatalasemic mice were significantly decreased (Figure 5). The size of the $\beta$ cells in the acatalasemic mice also significantly became small after alloxan administration.

\subsection{Insulin and C-Peptide Release from Pancreatic Islets Stimulated with Glucose}

We tried to isolate the islets of the acatalasemic mice 1, 3, 5 and 7 days after alloxan treatment, but were only able to isolate the islets 7 days after. The total DNA contents in the islet suspension of normal and acatalasemic mice were $226 \pm 57$ and $228 \pm 64 \mathrm{ng} / \mathrm{mL}$, respectively. Insulin and C-peptide releases from the ten isolated islets were summarized in Table 3. Both insulin and C-peptide releases were decreased by alloxan pretreatment, and the release from acatalasemic islets in response to $20 \mathrm{mM}$ glucose stimulation dramatically became low compared to the control one.

The stimulation indexes were calculated and summarized in Table 4. Both of the indexes were decreased by alloxan pretreatment. The C-peptide index was similar to that of insulin, as supported by the insulin index. The indexes in the acatalasemic mice were substantially lower than the normal ones.

\section{Discussion}

To examine the time-point at which mice suffer hyperglycemia after alloxan administration, we first examined blood glucose and insulin as well as oxidative markers in the blood. As blood glucose decreased and insulin increased on the first day after alloxan administration, it might be that alloxan temporary induced insulin release

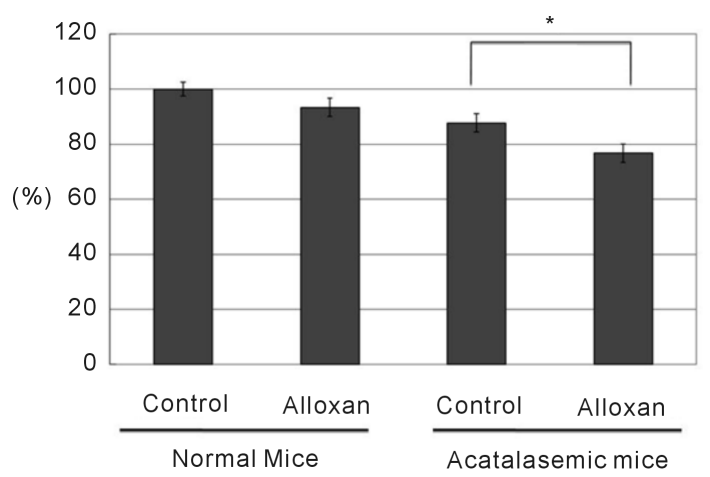

(a)

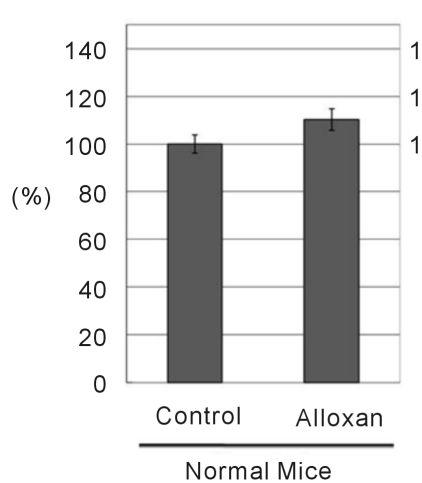

Normal Mice

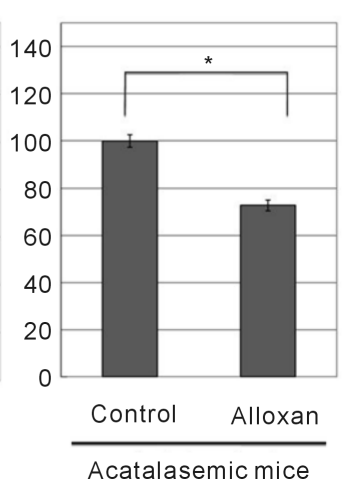

(b)

Figure 5. Relative number and the mean size of the $\beta$ cells in Langerhans islets 7 days after alloxan administration. Relative number of $\beta$ cells (a) and the mean size of the $\beta$ cells; (b) were compared to these (100\%) of control mice treated with PBS. The number of the control mice was $0.012 / \mu \mathrm{m}^{2}$. The sizes of control normal and acatalasemic mice were $62.4 \pm 2.4$ and 81.5 $\pm 2.2 \mu \mathrm{m}^{2}$, respectively. The bars of each symbol indicate the SE. *indicates $\mathrm{p}<0.05$.

Table 3. Amounts of insulin and C-peptide release from Langerhans islets ${ }^{*}$ stimulated with 3 and 20 mM glucose.

\begin{tabular}{cccccc}
\hline & & \multicolumn{3}{c}{ Concentration in supernatant (ng/mL) } \\
\hline \multirow{2}{*}{ Compounds } & $\begin{array}{c}\text { Glucose } \\
(\mathrm{mM})\end{array}$ & \multicolumn{2}{c}{ Normal mice } & \multicolumn{2}{c}{ Acatalasemic mice } \\
\cline { 3 - 6 } & 3 & $10.6 \pm 3.3$ & $5.6 \pm 1.9$ & Control (6) & Alloxan (4) \\
\hline Insulin & 20 & $27.0 \pm 7.0$ & $7.5 \pm 2.5^{* *}$ & $6.6 \pm 1.8$ & $5.7 \pm 1.9$ \\
Insulin & 3 & $15.3 \pm 5.8$ & $10.9 \pm 3.7$ & $12.0 \pm 0.2$ & $4.0 \pm 2.0^{* *}$ \\
C-peptide & 20 & $37.0 \pm 10.0$ & $16.0 \pm 8.0^{* *}$ & $33.0 \pm 0.02$ & $8.0 \pm 6.0^{* *}$ \\
C-peptide & 3 & Control (5) & $10.8 \pm 6.3$ \\
\hline
\end{tabular}

${ }^{*}$ The islets were isolated 7 days from mice treated with alloxan (200 mg/kg of body weight) or PBS (as a control). Number in parenthesis indicated the number of mice. ${ }^{* *} \mathrm{p}<0.05$ compared to each control group. 
Table 4. Stimulation index (SI) of insulin and C-peptide from Langerhans islets* ${ }^{*}$ stimulated by glucose.

\begin{tabular}{ccccc}
\hline & \multicolumn{2}{c}{ Stimulation index $^{* *}$} \\
Compounds & \multicolumn{2}{c}{ Normal mice } & \multicolumn{2}{c}{ Acatalasemic mice } \\
\cline { 2 - 5 } & Control (5) & Alloxan (3) & Control (6) & Alloxan (4) \\
\hline Insulin & $4.6 \pm 2.6$ & $1.4 \pm 0.6^{* * *}$ & $2.2 \pm 0.9$ & $0.7 \pm 0.3^{* * *}$ \\
C-peptide & $2.7 \pm 1.6$ & $1.6 \pm 0.8^{* * *}$ & $1.7 \pm 0.5$ & $0.6 \pm 0.3^{* * *}$ \\
\hline
\end{tabular}

${ }^{*}$ The islets were isolated 7 days from mice treated with alloxan $\left(200 \mathrm{mg} / \mathrm{kg}\right.$ of body weight) or PBS (as a control). ${ }^{* *}$ Stimulation index = each insulin (or C-peptide) concentration at $20 \mathrm{mM}$ glucose/the concentration at $3 \mathrm{mM}$ glucose. ${ }^{* * *} \mathrm{p}<0.05$ compared to the index of the control.

from islets of Langerhans in the pancreas [10] [11]. After 3 days, the insulin levels in the normal and acatalasemic bloods became lower than that of the controls and the level in the acatalasemic blood was lower than that in normal blood. The blood glucose level in the acatalasemic mice dramatically increased compared to that in normal mice 3 days after alloxan administration (Figure 1), and the incidence of hyperglycemia in acatalasemic mice was higher than normal mice. Oxidative markers in the blood of both mice increased after alloxan administration and gradually decreased but kept for more than 7 days. From these results, we confirmed that pancreas, especially the acatalasemic one, was sensitive to alloxan-induced oxidative stress thus resulting in hyperglycemia.

After alloxan administration, increase of apoptotic cells associated with decrease of number and the mean size of $\beta$-cells stained by insulin antibody (Figure 5) was observed in the acatalasemic mice but not in normal mice as previously reported [7]. Apoptosis cells in acatalasemic mice immediately increased, and the incidence was considerably small (less than 6.2\%). However, hyperglycemia in acatalasemic mice was observed 3 days after alloxan administration (Figure 1), and the incidence was large (27\%). To explain these phenomena, proteincarbonyl and 8-OHdG immunohistochemical stains of the pancreas were examined. A mild increase of the carbonyl-stained protein was observed in the islets of the alloxan-treated mice (Figure 4), and the staining of 8-OHdG from DNA degradation was hardly detected in pancreatic cells. These results suggested that the protein was oxidized rather than that the DNA was degraded by alloxan administration, suggesting that alloxan induced other damage than apoptosis in pancreas. As alloxan induced low insulin in blood (Figure 2), pancreatic islets from mice pretreated with alloxan were isolated. Insulin and C-peptide releases from the islets were examined under $3 \mathrm{mM}$ and $20 \mathrm{mM}$ glucose (Table 3) and calculated their insulin and C-peptide stimulation indexes [19] (Table 4). By alloxan pretreatment, insulin release from the islets was reduced, especially at $20 \mathrm{mM}$ glucose stimulation, resulting low insulin indexes. It indicated that glucose-dependent insulin secretion ability of the islets had deteriorated. Insulin release from the islets of the acatalasemic mice was reduced compared to that of normal mice, suggesting that acatalasemic mice were not able to release enough insulin for the body even under hyperglycemic conditions. We deduced that insulin release ability from the islets is an important factor for the onset of hyperglycemia. This deterioration in pancreas may be in part similar to that of type 2 diabetes induced by chronic exposure to elevate levels of glucose and free fatty acid [12]. As the islets are impacted by the intracellular redox state [20], further study is currently underway on the insulin release from beta cells under glucose stimulation.

\section{Conclusion}

Pancreatic beta cells of acatalasemic mice are highly susceptible to alloxan-induced oxidative stress. The stress induced deterioration of glucose-dependent insulin secretion ability from the islets of Langerhans. The deterioration in the islets mostly contributed to hyperglycemia, rather than the apoptosis.

\section{Acknowledgements}

N. M. thank Dr. Sen-ichi Oda, Department of Zoology, Faculty of Science, Okayama University of Science, and Dr. Shuhei Nakaji, Department of Biomedical Engineering, Faculty of Engineering, for their helpful discussion.

\section{References}

[1] Wang, D.H., Masuoka, N. and Kira, S. (2003) Animal Model for Oxidative Stress Research-Catalase Mutant Mice. Environmental Health and Preventive Medicine, 8, 37-40. http://dx.doi.org/10.1007/BF02897924 
[2] Takahara, S. and Miyamoto, H. (1948) Three Cases of Progressive Oral Gangrene Due to Lack of Catalase in the Blood. Nippon Jibiinkoka Gakkai Kaiho, 51, 163. (in Japanese)

[3] Aebi, H.E. and Wyss, S.R. (1978) Acatalasemia. In: Stanbury, J.B., Wyngaarden, J.B. and Fredricson, S., Eds., The Metabolic Basis of Inherited Disease, 4th Edition, Mcgraw-Hill, New York, 1792-1807.

[4] Goth, L. and Eaton, J.W. (2000) Hereditary Catalase Deficiencies and Increase Risk of Diabetes. The Lancet, 354, 1820-1821. http://dx.doi.org/10.1016/S0140-6736(00)03238-4

[5] Feinstein, R.N., Braun, J.T. and Howard, J.B. (1967) Acatalasemic and Hypocatalasemic Mouse Mutants: II. Mutational Variations in Blood and Solid Tissue Catalases. Archives of Biochemistry and Biophysics, 120, 165-169. http://dx.doi.org/10.1016/0003-9861(67)90609-1

[6] Takemoto, K., Tanaka, M., Iwata., H, Nishihara, R., Ishihara, K., Wang, D.H., Ogino, K., Taniuchi, K. and Masuoka, N. (2009) Low Catalase Activity in Blood Is Associated with the Diabetes Caused by Alloxan. Clinica Chimica Acta, 407, 43-46. http://dx.doi.org/10.1016/j.cca.2009.06.028

[7] Kikumoto, Y., Sugiyama, H., Inoue, T., Morinaga, H., Takiue, K., Kitagawa, M., Fukuoka, N., Saeki, M., Maeshima, Y., Wang, D.H., Ogino, K., Masuoka, N. and Makino, H. (2010) Sensitization to Alloxan-Induced Diabetes and Pancreatic Cell Apoptosis in Acatalasemic Mice. Biochimica et Biophysica Acta, 1802, 240-246. http://dx.doi.org/10.1016/j.bbadis.2009.10.009

[8] Kamimura, W., Doi, W., Takemoto, K., Ishihara, K., Wang, D.H., Sugiyama, H., Oda, S. and Masuoka, N. (2013) Effect of Vitamin E on Alloxan-Induced Mouse Diabetes. Clinical Biochemistry, 46, 795-798. http://dx.doi.org/10.1016/j.clinbiochem.2013.02.016

[9] Takemoto, K., Doi, W., Zukeran, A., Inoue, J., Ishihara, K. and Masuoka, N. (2014) Effect of Aspergillus awamoriFermented Burdock Root on Mouse Diabetes Induced by Alloxan-Prevention of Cell Apoptosis. Food and Nutrition Sciences, 5, 1554-1560. http://dx.doi.org/10.4236/fns.2014.516168

[10] Szkudelski, T. (2001) The Mechanism of Alloxan and Streptozotocin Action in B Cells of the Rat Pancreas. Physiological Research, 50, 537-546.

[11] Lenzen, S. (2008) The Mechanisms of Alloxan- and Streptozotocin-Induced Diabetes. Diabetologia, 51, $216-226$. http://dx.doi.org/10.1007/s00125-007-0886-7

[12] Cnop, M., Welsh, N., Jonas, J.C., Jorns, A., Lenzen, S. and Eizirik, D.L. (2005) Mechanism of Pancreatic Beta-Cell Death in Type 1 and Type 2 Diabetes: Many Differences, Few Similarities. Diabetes, 54, S97-S107. http://dx.doi.org/10.2337/diabetes.54.suppl 2.S97

[13] Masuoka, N., Wakimoto, M., Ubuka, T. and Nakano, T. (1996) Spectrophotometric Determination of Hydrogen Peroxide: Catalase Activity and Rates of Hydrogen Peroxide Removal by Erythrocytes. Clinica Chimica Acta, 254, 101112. http://dx.doi.org/10.1016/0009-8981(96)06374-7

[14] Gao, D., Li, Q., Liu, Z., Li, Y., Liu, Z., Fan, Y., Li, K., Han, Z. and Li, J. (2007) Hypoglycemic Effects and Mechanisms of Action of Cortex Lycii Radicis on Alloxan-Induced Diabetic Mice. Yakugaku Zasshi, 127, 1715-1721. http://dx.doi.org/10.1248/yakushi.127.1715

[15] Nam, S.Y., Lee, M.K. and Sabapathy, K. (2008) The Tumour-Suppressor p53 Is Not Required for Pancreatic Beta Cell Death during Diabetes and upon Irradiation. The Journal of Physiology, 586, 407-417. http://dx.doi.org/10.1113/jphysiol.2007.142612

[16] Zhang, N., Komine-Kobayashi, M., Tanaka, R., Liu, M., Mizuno, Y. and Urabe, T. (2005) Edaravone Reduces Early Accumulation of Oxidative Products and Sequential Inflammatory Responses after Transient Focal Ischemia in Mice Brain. Stroke, 36, 2220-2225. http://dx.doi.org/10.1161/01.STR.0000182241.07096.06

[17] Nakamura, A. and Goto, S. (1996) Analysis of Protein Carbonyls with 2,4-Dinitrophenyl Hydrazine and Its Antibodies by Immunoblot in Two-Dimensional Gel Electrophoresis. The Journal of Biochemistry, 119, 768-774. http://dx.doi.org/10.1093/oxfordjournals.jbchem.a021306

[18] Lacy, P.E. and Kostianovsky, M. (1967) Method for the Isolation of Intact Islets of Langerhans from the Rat Pancreas. Diabetes, 16, 35-39. http://dx.doi.org/10.2337/diab.16.1.35

[19] Sasamoto, H., Futami, M., Ando, Y. and Nakaji, S. (2012) Cryopreservation of Rat Islets of Langerhans by Vitrification. Journal of Artificial Organs, 15, 283-289. http://dx.doi.org/10.1007/s10047-012-0635-7

[20] Rebelato, E., Abdalkadel, F., Curi, R. and Carpinelli, A.R. (2011) Control of the Intracellular Redox State by Glucose Participates in the Insulin Secretion Mechanism. PLoS ONE, 6, e24507. http://dx.doi.org/10.1371/journal.pone.0024507 